\title{
モアレ写真を利用したコンピューター画像 処理による歯根表面積の測定
}

\author{
九州歯科大学口腔解剖学第 1 講座（主任：山田 博教授） \\ 小林繁・高田英幸・荒井秋 晴 \\ 伊東励・山田博
}

昭和 62 年 4 月 24 日受付

\section{A Convenient Computer-aided Measurement of the Dental Root Surface Area with Moiré Photographs}

\author{
Shigeru Kobayashi, Hideyuki Takata, Shusei Arai, \\ Rei Ito and Hiroshi Yamada \\ First Department of Oral Anatomy (Chief: Prof. Hiroshi Yamada) \\ Kyushu Dental College, Kitakyushu 803, Japan
}

The functional forces depending on the bite, tongue and cheek, and the artificial forces caused by the prosthetic or orthodontic mechanism are absorbed by the periodontal ligament. The dental root surface area is closely related to support of the periodontal ligament. The same applies to the shape of the root, the attachment direction and the implanted condition. Few reports, however, have been made on the subject of the measurements of the root surface area. We devised a new method to measure the root surface area using computer analysis of the moiré, and gained the following conclusions;

1) The dental root surface area along with the computer analysis of the moire was determined without damaging the teeth.

2) The sectional interval was reduced by the moiré and the precision was increased.

3) The method using the moiré and computer is superior in working capacity compared with past methods.

Key words: Dental root surface area/Moiré photograph/Computer analysis

\section{緒言}

咀嚼圧, 舌圧および煩圧などの機能的圧力や Crown bridge, Partial denture などの補綴装置または矯正 装置などを介して，雨牙に加わる圧力は䨑根膜により抵 抗される. これらの圧力の歯根膜への負担能力は, 歯根
形態，䊝牙の植立方向および骨植状態などと同様に，畨 根表面積之密接な関係にある。しかし, 歯根表面積は雪 根が小さく，その形態が不定形であるため，測定困難 であり，報告例も少ない，测定方法はそれぞれ異なる が，主に阪口 $(1940)^{11}$ ，山中ら $(1969)^{21}$, Tylman $(1970)^{3)}$ ，Luthra $(1974)^{4}$ ，羽賀ら $(1975)^{5)}$ および 
小田（1976）61などの報告があるに過ぎない。

著者らは先にモアレ写真のコンピューター解析によ り，雪牙咬合面の立体計测を行った 応用して雪根表面積の測定を行ったので報告する.

\section{材料および方法}

計測用粜牙には，奇形や雬根部実質欠損がなく，かつ 根長 $11 \mathrm{~mm}$ 前後の 標準的な上顎中切歯 10 本が用いられ た。

各歯牙は鮮明なモアレ縞を得るために,小林ら(1985) $\left.{ }^{8}\right)$ に従い Occlude によるコーティング処理が施された。 続くモアレ写真撮影とコンピューターによる画像解析に 用いられた装置と方法は, 殆ど小林ら (1985) ${ }^{7}$ に徉っ た。なお，モアレ写真撮影に際しては近心側の撮影終了 後，歯根軸を中心に茵牙を 180 度回転させ，遠心側の撮 影を行った。得られたモアレ像は23.3倍に拡大されトレ 一スされた後に，コンピューターに入力された．Fig.1 に近心側のモアレ写真とそのトレース像を示した。

蒋根表面積の算出法は次の通りである.

円錐台 $\mathrm{A}$ （Fig. $2-\mathrm{A}$ ） を間隔 $\boldsymbol{h}$ で $\boldsymbol{n}$ 個に等分し，そ の一つの円錐台B（Fig. 2-B）の側面積 $S_{m}$ は，下面 と上面の円周をそれぞれ $\ell_{m}, \ell_{m+1}$ とすれば(記号につ いては Fig. 2-Bを参照),

$$
S_{m}=\frac{1}{2} \cdot h^{\prime} \cdot\left(\ell_{m}+\ell_{m+1}\right)
$$

なお

$$
\gamma_{m}=\frac{\ell_{m}}{2 \pi}, \quad \gamma_{m+1}=\frac{\ell_{m+1}}{2 \pi}
$$
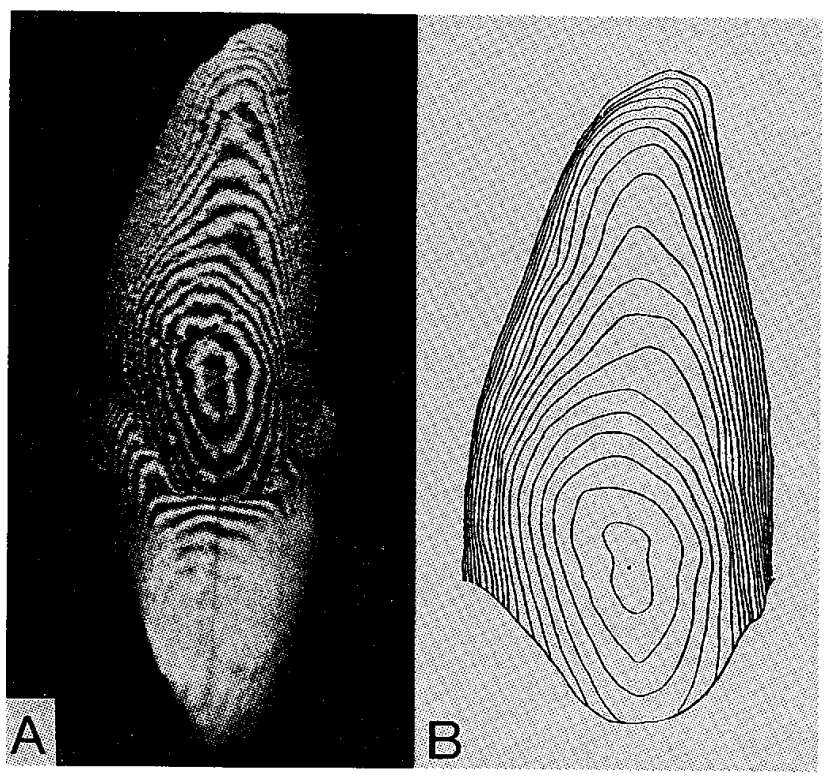

Fig. 1 Moiré photograph on the mesialis (A) and the trace of moiré (B)
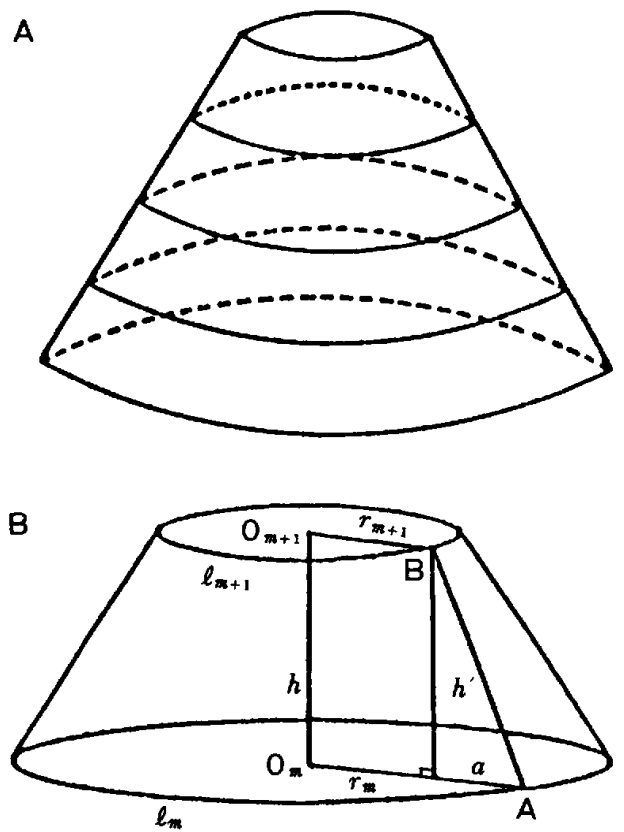

Fig. 2 Diagrams to show the simple interest formula for the lateral area in a frustum of cone

A; a regular cone divided horizontally into $n$ equal parts, B; a regular cone divided vertically into $k$ equal parts

$$
a=r_{m}-r_{m+1}=\frac{\ell_{m}-\ell_{m+1}}{2 \pi}
$$

故に

$$
h^{\prime}=\sqrt{a^{2}+h^{2}}=\sqrt{\frac{\left(\ell_{m}-\ell_{m+1}\right)^{2}}{4 \pi^{2}}+h^{2}}
$$

(1)に代入して

$$
S_{m}=\frac{\left(\ell_{m}+\ell_{m+1}\right)}{2} \cdot \sqrt{\frac{\left(\ell_{m}-\ell_{m+1}\right)^{2}}{4 \pi^{2}}+h^{2}}
$$

従って, 円錐台 $\mathrm{A}$ の側面積 $S$ は

$$
\begin{aligned}
S & =S_{1}+S_{2}+\cdots \cdots+S_{m}+\cdots \cdots+S_{n} \\
& =\sum_{m=1}^{n} S_{m}
\end{aligned}
$$

以上の事から，一つの円錐台の側面積 $S_{m}$ は，区分求 積法により下面と上面の周長および高さが決定されれば 算出できる，従って，下面周長 $\ell_{m}$ と上面周長 $\ell_{m+1}$ は モアレ縞からコンピューターによって求め，高さんは モアレの格子ピッチとした．との操作を蒾根の近心側と 遠心側でそれぞれ行い，得られた両者の面積を合計し て，歯根の表面積 $S$ とした。

他方，以上の方法によって得られた結果を比較検討す 
るため, 同一菌牙にアルミニウム䇴と薄いワックスプレ 一ト（厚さ0.30mm） を茵根に巻き付けて, 粜根表面積 を求める方法を平行して行った。巻き付けられた両者の 各面積はデジタイザーを使って, Cosmozone 98 system 1 によって求められた。

\section{結果および考察}

\section{1. 機械的および人為的誤差}

モアレ縞を利用して蒾根表面積を求めるための各好理 段階で，機械的あるいは人為的なさまざまな䓵差が考え られる. 特に, 㐘牙をコーティングするときの膜厚によ る䛊差，モアレ縞の太さとそのトレース時の誤美，およ びデジタイザーの感度とそれを使ってコンピューターへ 入力する時の誤差などがある，膜厚についてはなるべく 薄くコーティングし，トレース時の䛊差については 1 本 のモアレ縞の中間をなるべく正確にトレースするように 心がけた。

デジタイザー感度と入力時の人為的誤差について, 理 論的に周長の知られている 5 つの同心円を実際に入力す るととにより検討した。 その結果，理論的周長とコンピ ューターを使って求めた周長との間には有意な誤差か認 められなかった（Table 1).

Table 1 Results of the tests of precision

\begin{tabular}{cccc}
\hline No. & $\begin{array}{c}\text { Theoretic } \\
\text { value }\end{array}$ & $\mathrm{N}$ & $\mathrm{M} \pm \mathrm{SE}$ \\
\hline 1 & 12.560 & 24 & $12.576 \pm 0.018$ \\
2 & 25.120 & 24 & $25.214 \pm 0.016$ \\
3 & 37.680 & 24 & $37.809 \pm 0.014$ \\
4 & 50.240 & 24 & $50.350 \pm 0.012$ \\
5 & 62.800 & 24 & $62.943 \pm 0.020$ \\
\hline
\end{tabular}

SE, Standard error

定型テスト・ピースを用いて全処理段階に含まれる誤 差の検討を行ったこれまでの報告では, Jepsen (1963) ${ }^{91}$ と小田ら (1982)10'が membrane technique 法でそ れぞれ誤差 $1 \%$ と $4.2 \pm 0.3 \%$ で，小田 $(1976)^{6)}$ か膜重 量換算法で $0.7 \%$ であったとしている.

著者らが今回行った詋考の検討は，操作上の全ての䛊 差につい行ったものではない，本検定による誤差は殆ど 認められなかったが，今後著者らの方法に扔いても，定 型テスト・ピースを用いて真の表面積との誤差の検討を 行わなければならない。

\section{2. 菌根表面積}

今回使用した 10 本の柬牙の大きさを Table 2 に示し
た。

これらの歯牙を用い，歯根の近心側と遠心側における モアレ縞の周長を求め，それらの周長から各歯根の表面 積を算出した（Table 3 ）。なお，Table 3 にはモアレ 縞によって得られた表面積（以下，モアレ法という）の ほかに，アルミニウム泾を使って求められた表面積（ア ルミホイル法）とワックスプレートにより得られた表面 積（ワックスプレート法）の結果もそれぞれ併記した

Table 2 Measurements ( $\mathrm{mm}$ ) of the teeth

\begin{tabular}{rcccc}
\hline \hline No. & Lt & Lr & Md & Ld \\
\hline 1 & 22.5 & 11.3 & 6.8 & 6.6 \\
2 & 21.6 & 11.0 & 6.5 & 6.4 \\
3 & 24.2 & 11.0 & 5.8 & 6.7 \\
4 & 21.6 & 11.0 & 6.6 & 6.4 \\
5 & 21.3 & 11.2 & 5.9 & 5.1 \\
6 & 21.8 & 10.6 & 5.7 & 6.2 \\
7 & 21.4 & 11.4 & 6.6 & 6.4 \\
8 & 21.6 & 11.6 & 6.2 & 6.2 \\
9 & 20.6 & 11.5 & 6.3 & 6.7 \\
10 & 22.2 & 11.7 & 5.8 & 5.9 \\
\hline
\end{tabular}

Lt, Length of tooth; Lr, Length of root; Md, Mesiodistal diameter of root at the cervix; Ld, Labiolingual diameter of root at the cervix

Table 3 Measurements of the dental root surface area by the methods of moiré $(\mathrm{MO})$, aluminium foil (AF) and wax-plate (WP)

\begin{tabular}{rrrr}
\hline No. & MO & AF & WP \\
\hline 1 & 175.2 & 173.7 & 205.1 \\
2 & 133.2 & 173.1 & 200.1 \\
3 & 148.8 & 200.0 & 213.0 \\
4 & 165.3 & 181.8 & 202.0 \\
5 & 149.5 & 159.1 & 176.7 \\
6 & 180.6 & 169.4 & 170.7 \\
7 & 175.1 & 169.3 & 213.1 \\
8 & 167.1 & 189.3 & 200.7 \\
9 & 165.2 & 168.9 & 199.1 \\
10 & 136.7 & 150.0 & 167.2 \\
\hline $\mathrm{M} \pm$ SE & $159.7 \pm 5.0$ & $173.5 \pm 4.3$ & $194.8 \pm 5.1$ \\
\hline
\end{tabular}

SE, Standard error 
てれらの方法により求められた歯根表面積の各平均值 はモアレ法で最も小さく $\left(159.7 \mathrm{~mm}^{2}\right) ，$ アルミホイル 法 $\left(173.5 \mathrm{~mm}^{2}\right)$ ，ワックスプレート法 $\left(194.8 \mathrm{~mm}^{2}\right)$ の 順に大きくなった。てれは求積方法と材質の相違による ものと思われる. 表面仿縞を投影して求めるモアレ法の 結果より，歯牙汇巻き付けて求めるアルミホイル法が， またアルミホイル法より材質が厚く伸張し易いワックス プレート法が，それぞれ過大評価になることは容易に予 想できる.

しかし，個々の歯牙についてみると，歯牙番号No. 6 と No. 7 では必ずしも上述の傾向を示していない．と れは，両雬の歯根表面が他の歯牙に比べて山凸に富んで いるためと思われる。 また，歯牙番号 No. 2 と No. 3 では，乙れらの㐘牙の大きさが他の蒾牙と比べて大美な いにもかかわらず，モアレ法による結果が他の 2 方法に よる結果よりかなり小さい值を示した（Table 3)。乙 れは，両菌牙の崡根形態が他の歯牙に比べ角張ってお り, モアレ縞が辺縁部で密になるため, 縞の正確なトレ 一スが困難で, やや過小評洒になったものと思われる.

他方，乙れまでに報告された中から，我々と同様な区 分求積法を応用した山中ら $(1969)^{21}$ と羽賀ら $(1975)^{5}$ は，䈖根を小さな円柱の和と仮定している，従って，て の方法は我々が円錐台の和と仮定したのに比べ，理論的 により大きな䛊差を生じると考えられる．更に，彼らの 方法は姏理段階が複雑であり，両者の結果も大きく異な っている。
また小田ら $(1982)^{10}{ }^{\prime}$ は，歯根面への密着性に問題の ある阪口（1940） ${ }^{1}$ の方法や，操作性に問題のある小田 $(1976)^{6}{ }^{\prime}$ の方法に比べ, 酢酸ビニルと $\alpha$-シアノアクリ レート系モノマーを用いた彼らの方法が簡便で精度も高 いことを指摘している。

そこで，小田ら (1982)10) と我々のモアレ法（Table 3）とにおける上顎中切㐘の菌根表面積の平均値を比較 すると, 前者が $203.0 \mathrm{~mm}^{2}$, 後者が $159.7 \mathrm{~mm}^{2}$ であっ た。供試された曾牙が異なるため, これらの值を直接比 較することはできない，しかし，前者の平均根長が 14.4 $\mathrm{mm}$ であるのに対して, 後者のそれが11.2mm と短く, また各蒾牙の形態が異なることなどと考えあわせると， 両者の求積方法の違いによる差は小さいと考えられる.

以上の事から，今回用いたモアレ縞による面積の求め 万は, まだ問題が残されているものの，操作性に優れ， 比較的精度が高いととから, 非常に有効な方法であると 考えられる。

結論

モアレ縞を利用したコンピューター画像処理により， 上顎中切歯に抢ける柬根表面積を求める方法について考 察した。操作上含まれる誤差については今後まだ検討を 加えなければならない。しかし，モアレ縞による蒾根表 面積の計測法はメッキ法などに比べ操作性が簡単で, 比 較的高い精度を持つなどの点で有効な手段と考えられ た。

\section{引用 文 献}

1) 阪口 勇：本邦人永久柬柬根表面積の研究. 口病誌 $14: 93-95,1940$.

2) 山中喜男・梅村和弘・佐藤孝一・猪瀬勝也・吉中光六 : 永久菌歯根表面積の研究（第 1 報）。歯科学報 $69: 827-832,1969$.

3) Tylman, S.D. and Tylman, S.G. : Theory and practice of crown and bridge prosthodontics. 6th ed., The C.V. Mosby Company, St. Louis. : 190-193, 1970.

4) Luthra, S.P., Narayan, I. and Subrahmanyan, N. : Root surface area measured by benzen absorption method. J. Prosthet. Dent. 31:185-189, 1974.

5) 羽賀通夫・腰原 好・山中喜男・黒須 誠・佐藤正行・佐々木 康・五十嵐 栄：永久霜雨根表面積の研究 (第 2 報)。補綴誌 $18: 250-259,1975$.

6）小田展生：ヒトの歯根表面積に関する研究。九州歯会誌 $30: 582-599,1976$.

7 ）小林 繁・塘 総一郎・野代悦生・山田 博：コンピューター画像処理によるモアレ写真を利用した歯牙咬 合面の立体計測法。九州歯会誌 $39: 477-480,1985$.

8) 小林 繁・杉原瑛治・塘 総一郎・大津隆一・山田 博：モアレ写真撮影における歯牙表面のコーティング 方法. 九州雨会誌 $39: 474-476,1985$.

9) Jepsen, A. : Root surface measurement and a method for X-ray determination of root surface 
area. Acta Odont. Scand. 21:35-46, 1963.

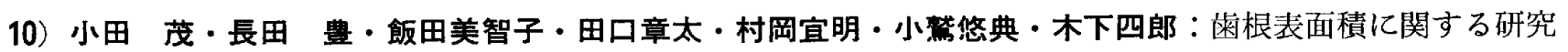
第 1 報 測定方法と雨根総表面積. 日歯周誌 $24: 285-292,1982$. 